\title{
The Destruction of Yemen and Its Cultural Heritage LAMYA KHALIDI
}

French National Center for Scientific Research, Cultures et Environnements, Préhistoire, Antiquité, Moyen Age, University of Nice Sophia Antipolis, Nice, France; e-mail: lamya.khalidi@cepam.cnrs.fr doi:10.1017/S0020743817000691

After losing control of the capital Sanaa to Yemen's northern Houthi movement, which is aligned with forces loyal to the former president 'Ali 'Abd Allah Salih, current Yemeni President 'Abd Rabbu Mansur Hadi turned to Saudi Arabia for help. In March 2015, Saudi Arabia and its coalition of nine states began a bombing campaign in Yemen, the poorest country in the Arab world. Prior to the conflict, Yemen was already 90-percent dependent on imported food and had been battling a severe water deficit. A twentyeight-month-long siege of its civilian population has left the country in a situation that some humanitarian groups deem to be worse than the crisis in Syria. ${ }^{1}$ The media has barely covered Yemen's catastrophic crisis, partially because of overt censorship by the Saudi kingdom and a shielding of its systemic violations of international law by powerful allies including the United States, the United Kingdom, and France. These countries are clearly more concerned with billion-dollar arms deals with the kingdom than with putting an end to what has been described as the worst food crisis since the establishment of the United Nations. ${ }^{2}$

Even less visible than the humanitarian catastrophe unfolding in Yemen has been the systematic degradation of the country's millennia-old cultural heritage by the coalition, its Yemeni opponents, and jihadi terrorist groups including the so-called Islamic State (IS). Tragically, much of this damage, notably that from Saudi air strikes and from demolitions carried out by the IS, appears to be intentional. ${ }^{3}$ The systemic destruction of the country's cultural heritage is in effect a targeting of its people and a gradual erasure of their cultural identity-once a point of unity amongst Yemenis.

Yemen's cultural heritage is as unique as it is universal, and those who value it most (often intuitively) are Yemenis themselves. It is the fingerprint of hundreds of thousands of years of human history and resilience, starting with the first waves of Homo sapiens migration out of Africa across the Bab al-Mandab strait 60,000 years ago, to the megalithic monuments, walled hilltop settlements, and desert necropolises of the Bronze Age (third-second millennium BCE), followed by the golden age of the Sabaean kingdoms ( $900 \mathrm{BCE}-520 \mathrm{CE}$ ) which controlled the incense caravan routes, built the Great Marib dam irrigating the desert, developed writing and a legal system, and built pillared stone temples to their gods.

If mentions of the region in the writings of Herodotus, ${ }^{4}$ Pliny, ${ }^{5}$ and Strabo 6 -including the unsurmountable difficulties encountered by Augustus's Roman legions under Aelius Gallus in trying to penetrate it between 26 and 24 BCE-are not enough to highlight the importance of this region and its dichotomous history of insularity and interaction, one need only add that this was also one of the most ancient cradles of Judaism, Christianity, and Islam, with the latter still visible in the mosque architecture and in Yemen's rich ancient Islamic archives. 
Yemen is a country of deserts, valleys, coastal landscapes, and spectacular mountains (3,666 $\mathrm{m}$ a.s.l.) watered by the tail end of the Indian monsoons. These landscapes meld with villages and cities built of mud and stone that are a testament to some of the most diverse and exceptional vernacular architecture in the world, recognized as such by UNESCO. Tim Mackintosh Smith captures the magical essence of this country when he writes that "the cities seemed to have been baked, not built, of iced gingerbread; Yemen was part of Arabia but the landscape looked like ... well, nowhere else on Earth."7

It is difficult to rationalize destruction of cultural heritage in any context, and even more so in this land where the past, the present, and the landscape are intricately interrelated. Since March 2015, counts of damaged or destroyed archaeological sites (ten), museums (eight), mosques (ten) and churches (two), tombs (over seventeen), monuments and old cities, and UNESCO World Heritage Sites (six) exceed seventyeight according to the official Yemeni list. ${ }^{8}$ Fifty-nine of these have been damaged or destroyed by Saudi coalition bombs (seventeen in the range of 70 to 100 percent destroyed) despite the coalition having been handed by UNESCO no fly lists of cultural heritage to avoid. Two sites have been damaged by opposition forces and the remaining seventeen were damaged by explosives detonated by al-Qa ida and the IS (thirteen of these are in the range of 70 to 100 percent destroyed and one of them includes six tombs). Three of these damaged sites are UNESCO World Heritage Sites and include the historic cities of Sanaa, Zabid, and Shibam, while three others-Thula, Marib, and Saada - are on the tentative list of UNESCO World Heritage Sites.

Coalition bombs hit Sanaa's old city housing 106 mosques and 6,500 homes in March, June, and September 2015, targeting two neighborhoods. The collateral damage of bombing raids across Sanaa city has done additional damage to the houses in the old city. For example, most of the ancient alabaster windows have broken from the force of the bombings. In addition, an ancient mosque, Qubbat al-Mahdi $(1750 \mathrm{CE})$ in old Sanaa was damaged by the IS in June 2015 .

The historic city of Zabid which houses eighty-six mosques and was the capital of Yemen between the 13th and 15th centuries was also hit by Saudi coalition bombs in May 2015. The bombs hit a restaurant in the fabled city and the force of the explosions brought down several historic homes. The picturesque old city of Shibam in Hadramawt, known as the Manhattan of the desert for its fourteen-story mud skyscrapers, was damaged by al-Qa ida in November 2016.

The Marib dam, its temples, and the ancient city of Marib are among many features included in the Marib archaeological site, which is on the tentative list of UNESCO World Heritage Sites. As the capital of the kingdom of Saba, its ruins have been excavated for decades by numerous archaeological missions, and it is one of the most iconic archaeological regions in Yemen. The Marib dam is mentioned in the Old Testament and the Qur'an, and was the largest dam built in antiquity, watering an area of 24,000 acres during the Sabaean period, over 2,500 years ago. The Ma'rib dam has also been bombarded repeatedly by coalition bombs and was severely damaged in areas, as was the ancient city of Ma'rib.

Other damaged sites still not recognized by UNESCO include the archaeological site of Sirwah, also bombarded by the coalition in April and May 2015, and the archaeological site of Baraqish, bombed by coalition forces in September 2015. The bombs destroyed a part of the ancient city wall of Baraqish and the Italian archaeological project's 
fieldhouse. In March and April 2016, Baraqish was bombed again, destroying 70 percent of the 4th-century BCE Temple of Nakrah. Shibam-Kawkaban's gate and citadel, which were built in the 7th century BCE by a Sabaean king, were wiped out by Saudi aerial bombardments in February 2016.

In addition, there has been damage from coalition bombardment (collateral or direct) to museums such as the National Museum in Sanaa, the Attaq archaeological museum in Shabwa, Qasr Sala commissioned by Imam Yehya, now the archaeological museum of Taiz (50\% damaged), and Qasr al 'Abdali, both a historical monument and a museum in Aden. The most flagrant of these bombing campaigns was the total destruction of the Dhamar Archaeological Museum, which housed upward of 12,500 objects, not including massive quantities of unregistered archaeological remains stored there by active archaeological field programs. It was pulverized by coalition bombs in May 2015.

In addition to the seventy-eight confirmed sites, irreparable damage to architecture, museum collections, and archaeological sites was incurred as a result of collateral damage from ground combat and aerial bombing, lack of upkeep, and looting of sites by locals and foreign forces made possible as a result of the chaos and lawlessness that now reigns, and facilitated by acts of desperation and hunger. All of these factors have further enabled a traffic in recently stolen and looted antiquities only just beginning to appear on the market and in private collections.

This is the sorry state of affairs after more than two years. The UN has demonstrated time and again that it is incapable of being impartial. Thus, it chose to remove Saudi Arabia from the UN High Commissioner's list of grave violators of children's human rights after the kingdom threatened to withdraw its funding; in the last year the kingdom has been elected to the UN Human Rights Council and more recently to the UN Women's Rights Council. Meanwhile, the Obama administration agreed to over 130 billion dollars in arms deals with the coalition states, providing refueling and logistical support to the coalition air force that is bombing civilians, infrastructure, and monuments in Yemen. Donald Trump has now signed an additional multibillion-dollar arms deal with Saudi Arabia. The United States is not the only Western power complicit in these war crimes: the United Kingdom, France, and now Australia have also engaged in arms deals with the Saudi monarchy since the beginning of the conflict.

Just as the coordinates of hospitals and World Food Program food warehouses were and continue to be given repeatedly to the coalition so that they are protected from air raids, ${ }^{9}$ so were site and monument coordinates, and all have been repeatedly hit by USmade bombs from coalition planes. This may simply be one of many forms of "archaeology of power" which Lynn Meskell describes as a "means to obliterate, silence and negate other histories and ways of dwelling in the same space." 10 Violence is evidently not new to heritage construction. What is shocking, however, is the impotence of multilateral institutions and international media to expose and oppose the blatant state-sponsored and western-backed destruction of Yemen's heritage that ultimately serves to legitimize ${ }^{11}$ and normalize heritage destruction by select powerful actors. Meanwhile, similar acts when carried out by jihadist groups like the IS are rightly universally condemned.

The humanitarian situation is dire and an end to the violence is needed, but it can only be achieved if Saudi Arabia's siege of Yemen is stopped and the kingdom and its allies are held accountable. A just local solution needs to be found quickly to restore 
order and stability to a country and a people whose resilience has been severely depleted by nothing short of forced starvation. Without this, the violence will increase as the situation worsens and the strength and territory of jihadi Islamist groups grow further. ${ }^{12}$ Most importantly, it is essential that the tangible and intangible heritage of Yemen that is unique and irreplaceable, and the people who are responsible for it, be protected.

Heritage cannot and will not be protected without a just end to the fighting. The only short-term means to protect heritage during this crisis is finding ways of providing material and financial support to local archaeologists so that they can track damage, protect museum collections, and repel looters. Meanwhile, archaeologists and the world community must actively oppose the Saudi-led war and blockade of Yemen as well as the looting of antiquities, which fuel an illicit market and expand the private holdings of greedy collectors.

\title{
NOTES
}

\begin{abstract}
${ }^{1}$ Today more than 10,000 civilians are dead due to the fighting, without counting deaths from malnutrition and medical issues resulting from Saudi blockades keeping critical medical supplies, food, and fuel from reaching areas most in need. About 2,600 of those are children and 2,000 are women. In addition, the toll of wounded in the fighting is around 40,000 and approximately 3.1 million people are internally displaced.

${ }^{2}$ According to the World Health Program and Oxfam, 20 million of a population of close to 28 million are in desperate need of humanitarian aid and 17 million are battling hunger and malnutrition, 7.6 million of whom are on the brink of famine. Seventy percent of Yemen's food comes through the port of Hodeidah, which is constantly bombarded and blockaded by Saudi Arabia and its coalition (OCHA), with looming threats of an assault on the Houthi-held port that would further decrease food supplies to the majority of Yemen's population. Ninety percent of the country's sanitation infrastructure has been destroyed by bombing campaigns, exacerbating a cholera epidemic caused by contaminated water supplies. To date cholera has affected 400,000 people and killed 1,900 and counting. UNOCHA-UNHCR-UNICEF-WFP-WHO, accessed 18 August 2017, http://www.wfp.org/news/news-release/statement-heads-unicef-wfp-and-who-following-visit-yemen.
\end{abstract}

${ }^{3}$ Lamya Khalidi, "Yemeni Heritage, Saudi Vandalism," The New York Times, 26 June 2015.

${ }^{4}$ Herodotus, The Histories, Book III, c. 430 BCE.

${ }^{5}$ Pliny the Elder, Natural History, vi. 32.

${ }^{6}$ The Geography of Strabo published in vol. 1 of the Loeb Classical Library edition, 1917, xvi.

${ }^{7}$ Tim Mackintosh Smith, Yemen: The Unknown Arabia (New York: Overlook Press, 2014).

${ }^{8}$ The list is provided by Muhannad al-Sayani, director of the Yemeni General Organization of Antiquities and Museums (GOAM), and is continually updated once there is ground confirmation of site destruction or damage. Many sites appear on the list months after they have been damaged because of difficulty of access to certain areas due to heavy bombing campaigns, ground fighting, and the damage to roads and infrastructure. An infographic of data compiled by the Legal Center for Rights and Development, a civil society organization based in Sanaa that has been closely following the coalition bombardments since 2015, shows that the Saudi coalition has hit scores of mosques (712) and archaeological sites (206). Though its counts are higher than official GOAM counts and include modern mosques, they are likely to be closer to actual numbers given the extent of the bombardments and the difficulty of access to sites encountered by GOAM to officially verify each case on the ground.

${ }^{9}$ Despite systematically giving hospital coordinates to the Saudi coalition, four clinics held by Doctors Without Borders (MSF) have been bombarded.

${ }^{10}$ Lynn Meskell, “Archaeology Matters," in Archaeology Under Fire: Nationalism, Politics and Heritage in the Eastern Mediterranean and Middle East, ed. Lynn Meskell (London: Routledge, 1998), 5.

${ }^{11}$ See Rosie Bsheer's contribution to this roundtable.

${ }^{12}$ James Spencer, "The GCC Needs a Successful Strategy for Yemen, Not Failed Tactics," in Arabia Incognita: Dispatches from Yemen and the Gulf, ed. Sheila Carapico (Charlottesville, Va.: Just World Books, 2016), 293. 